SPORT - Nauka i Praksa, Vol. 11, №1, 2021, str. 35-42.

Pregledni naučni članak

\title{
ANALIZA TELESNOG SASTAVA: NAJČEŠĆI MODELI I METODE ISPITIVANJA ${ }^{1}$
}

\author{
UDK: 796:61 \\ 616-071.3 \\ https://doi.org/10.18485/snip.2021.11.1.5 \\ Dragan Đurđević \\ Medicinski fakultet, Katedra za medicinu sporta, Univerzitet u Beogradu, Srbija ${ }^{3}$
}

\begin{abstract}
Apstrakt: Tačna i validna analiza telesnog sastava je značajna za dijagnostiku nutritivnog statusa, procenu uticaja treninga, odgovora organizma na nutritivne i terapeutske intervencije, rast i razvoj organizma, procenu zdravstvenog rizika. Povećanjem oboljevanja od hroničnih nezaraznih bolesti, gojaznosti, povećala se potreba za različitim modelima i metodama analize telesnog sastava. Ovaj pregledni rad je imao za cilj da prikaže najčešće korišćene metode za analizu telesnog sastava i da da kratak uvid o trenutnim tehnikama. Metodi za analizu telesnog sastava variraju u svojoj tačnosti i pouzdanosti i u praksi upotreba odgovarajućeg metoda zavisi od interesa i potrebne tačnosti, npr. dvostruko-energetska rendgenska denzitometrija (DXA) kao gold standard za određivanje minerala u kostima, ili magnetna rezonanca (MRI) kao gold standard za analizu mekih tkiva i organa. Ove metode, uz kompjuterizovanu tomografiju (CT), hidrodenzitometriju i pletizmografiju, rutinski se primenjuju u kliničkoj medicini, a zbog svoje kompleksnosti, teže dostupnosti i visoke cene u sportskoj medicini se koriste najviše u istraživačke svrhe. U sportskoj medicini se najviše primenjuju antropometrijska metoda i bioelektrična impedansa (BIA), zbog svoje jednostavnosti i komfora za ispitanika. Najbolja procena telesne kompozicije se može dobiti kombinacijom više metoda - multi-komponentni model, čime se povećava tačnost i pouzdanost dobijenih podataka i sa većom sigurnošću se može proceniti zdravstveni rizik.
\end{abstract}

Ključne reči: telesni sastav, nutritivni status, antropometrija, DXA, BIA, sportska medicina

UVOD

Analiza telesnog sastava (BCA) je u sferi interesovanja sportskih stručnjaka, nutricionista i zdravstvenih radnika. Tačna i validna procena nutritivnog statusa, morfoloških i funkcionalnih kapaciteta ima značajnu ulogu u proceni uticaja treninga i postizanju vrhunskih rezultata sportiste, može se pratiti odgovor organizma na nutritivne i terapeutske intervencije, rast i razvoj organizma, odnosno unutrašnji i spoljašnji faktori na različitom biološkom nivou. Povećanjem oboljevanja od hroničnih nezaraznih bolesti, gojaznosti, došlo je do povećane potrebe za različitim modelima i metodama analize telesnog sastava u cilju objektivnog sagledavanja nutritivnog statusa, funkcionalnog kapaciteta, zdravstvenog rizika i morbiditeta. Prvenstveno gledano, interesovanje za analizu telesnog sastava nastalo je da bi se odredila masna masa (FM) tela. Napretkom tehnologije i boljim razumevanjem analize telesnog sastava i uticaja na zdravlje, dolazimo do novih mogućnosti za unapređenje trenutne prakse.

Analizom telesnog sastava, pored navedenog, dobijaju se i informacije koje pomažu da se identifikuje i proceni kaheksija, sarkopenija i gojaznost. Kaheksija je stanje koje prati gubitak masnog tkiva i mase skeletnih

Rad primljen: 21.6.2020, korigovan: 9.7.2020, prihvaćen za objavljivanje: 9.7.2020.

$\triangle$ d djurdjevic@yahoo.com

Dragan Đurđević je doktorand Medicinskog fakulteta Univerziteta u Beogradu. 
mišića, koja je rezultat niza stanja, a najčešće je posledica odmaklog starenja ili malignih oboljenja. Sarkopenija je gubitak mišićne mase izazvan starenjem, dok je gojaznost hronično oboljenje, koje karakteriše prekomerno nakupljanje telesnih masti, koje dovodi do brojnih zdravstvenih komplikacija: hipertenzija, dijabetes melitus tip 2, metabolički sindrom, oboljenja srca i krvnih sudova, kičme, zglobova, psihički poremećaji (Bhatt, 2016; RodríguezHernández et al., 2013). Gojaznost je jedan od najvećih zdravstvenih problema u svetu i može se reći da poprima oblik pandemije. Pored odraslih, zabrinjavajuće je što je sve češće zastupljena i u dečijem uzrastu. Sve ovo je povezano sa smanjenjem funkcionalnih sposobnosti, povećanim morbiditetom i mortalitetom (Francis et al., 2017; Peterson \& Braunschweig, 2016). Rezultati Svetske zdravstvene organizacije (WHO) pokazuju da je u 2014. godini bilo 600 miliona odraslih i 42 miliona dece ispod pet godina starosti sa prekomernom telesnom težinom (WHO, 2016). Ovo govori koliko je važna identifikacija i upotreba validnih metoda i modela u analizi telesnog sastava.

\section{MODELI I METODE ANALIZE TELESNOG SASTAVA}

\section{Modeli}

Analiza telesnog sastava se može raditi direktnim i indirektnim merenjem. I pored toga što je direktno merenje najtačniji metod, s obzirom da zahteva seciranje tkiva, nije opcija za upotrebu. Kod indirektnog merenja postoje različiti modeli i tehnike.

Najviše upotrebljavani i osnovni model za analizu telesnog sastava je dvo-komponentni model (2C), gde je telo podeljeno na dva dela, na masnu (FM) i bezmasnu masu (FFM). 2C model je baziran na određivanju gustine tela i najčešće korišćena tehnika je hidrodenzitometrija. Pored $2 \mathrm{C}$ modela, postoji tro-komponentni model (3C), gde se FFM deli na dva dela, sadržaj vode i preostalu čvrstu materiju, koju pretežno čine proteini i minerali. Sledeći model, koji teoretski daje validnije rezultate od $3 \mathrm{C}$ modela, je četvoro-komponentni (4C) model, koji analizom tela daje rezultate za masti, minerale, ukupnu vodu (TBW) i proteine. Pored rezultata koji se dobijaju hidrodenzitometrijom, neophodno je dodatno da se koriste dvostruko-energetska rendgenska denzitometrija (DXA) za dobijanje tačnih podataka o vrednostima minerala u kostima i neutron aktivaciona analiza za dobijanje tačnih podataka o proteinima. $\mathrm{Na}$ osnovu navedenog, jasno je da se dodatnim merenjima širi broj ispitivanih komponenti u BCA (npr. količina kalcijuma, fosfora, azota, određivanje ekstracelularne vode) i da je neophodno da se merenje zasniva isključivo na nezavisnom dobijanju rezultata za tu komponentu, pa tako dolazimo do multi-komponentnog modela (MCM) telesne analize, kojim se dobija izuzetno puno podataka, ali zahteva kombinaciju različitih metoda merenja (Ellis, 2000; Kuriyan, 2018).

Prateći razvoj modela kroz vreme, Wang et al. su objedinili i predstavili model od pet nivoa telesnog sastava, koji je postao standard u istraživanju BCA (Wang et al., 1992).

\subsection{Pet nivoa telesnog sastava}

Trenutni modeli analize telesnog sastava se odnose na pet nivoa telesne kompozicije. Prvi je atomski nivo, koji sadrži glavne hemijske elemente (kiseonik, ugljenik, vodonik, azot, kalcijum i fosfor), a čijom se analizom mogu dobiti veoma važne informacije, kao što je npr. sadržaj azota, koji nam govori o ukupnoj količini proteina u telu, a vrši se neutronskom aktivacionom analizom. Drugi nivo se sastoji od glavnih molekularnih delova i to je molekularni nivo, gde spadaju voda, proteini, ugljeni hidrati, masti i minerali u kostima i mekim tkivima. Npr. esencijalne masti su veoma važne za funkciju ćelijske membrane. Dok se voda i minerali u kostima mogu odrediti direktnim putem (dilucija izotopa, DXA), ostalo se procenjuje indirektnim putem. Treći nivo je ćelijski, koji se sastoji od ćelijske mase (masti i bezmasna masa ćelije, gde se odvijaju metabolički procesi), ekstracelularnu tečnost i ekstracelularni matriks. Pokušavano je da se razviju određeni modeli, na bazi antropometrije, za procenu mase ćelija, ali nijedan nije u široj upotrebi. Četvrti je tkivno-organski nivo, koji se sastoji od tkiva, organa i sistema. Npr. adipozno tkivo je locirano kao subkutano i kao unutrašnje, odnosno visceralno. Procenjuje se indirektnim metodama (npr. ultrazvuk, CT). Poslednji nivo predstavlja nivo celog tela, odnosno organizma u celini, koji je podeljen na različite delove i gde je potrebno da se koriste različiti modeli i metode analize telesnog sastava multikomponentni model (WHO Expert Committee, 1995). 


\section{Metode}

\subsection{Antropometrijska merenja}

Antropometrija je široko rasprostranjena metoda kojom se meri masa tela, longitudinalna dimenzionalnost skeleta, transferzalna dimenzionalnost skeleta, obim i debljina kožnih nabora (SF), posebno u populaciji dece. Antropometrijske mere mogu pomoći za utvrđivanje razvoja tela, morfoloških karakteristika, uhranjenosti, odnosa FM i FFM, uticaj treninga i ishrane na organizam, nutritivnih intervencija, zdravstvenog rizika.

Još je 1921. godine razvijena jednačina za procenu telesnih masti na osnovu antropometrijskih mera, merenjem debljine kožnih nabora (Matiegka, 1921). Merenjem debljine kožnih nabora kaliperom dobijaju se mere kojima se kroz upotrebu jednačina procenjuje FM i FFM. Na osnovu najčešće korišćenih jednačina, najviše se meri na sledećih deset tačaka: triceps, subskapularna, trbušna, suprailiačna, butna, biceps, list, grudi, umbilikus, toraks (J. Wang et al., 2000). Da bi se dobile precizne mere, neophodna je upotreba dobro kalibrisanog kalipera (npr. Lange, Holtain) i kao što je pomenuto dobro obučenu osobu, koja sprovodi proceduru po standardizovanoj metodologiji. Posebnu pažnju treba obratiti na precizno lociranje tačaka, povlačenje kože i postavljanje instrumenta pod uglom od $90^{\circ}$. Najčešće korišćene jednačine za određivanje FM i FFM na osnovu mera dobijenih merenjem SF su Jackson i Pollock (Jackson \& Pollock, 1978; Jackson et al., 1980) i Durnin i Womersley (Durnin \& Womersley, 1974).

Antropometrijskim procedurama se, kao što je pomenuto, određuje i uhranjenost izračunavanjem indeksa telesne mase (BMI) i predstavlja najčešće korišćenu meru za određivanje prekomerne telesne težine i gojaznosti. Kod ispitanika se meri telesna masa (TM) i telesna visina (TV), a onda se na osnovu matematičke formule izračunava BMI:

$\mathrm{BMI}=\mathrm{TM}(\mathrm{kg}) / \mathrm{TV}(\mathrm{m})^{2}$

Na osnovu klasifikacije, koju je napravila Svetska zdravstvena organizacija (WHO), određuje se uhranjenost osobe i njen zdravstveni rizik (Tabela 1).

Tabela 1. WHO BMI klasifikacija

\begin{tabular}{lcc}
\hline Klasifikacija & BMI $\left(\mathrm{kg} / \mathrm{m}^{2}\right)$ & Rizik od kormobiditeta \\
\hline Pothranjenost & $<18,5$ & Nizak (drugi zdravstveni rizici) \\
\hline Normalan opseg & $18,5-24,9$ & Prosečan \\
\hline Prevelika težina & $>25$ & \\
\hline Predgojaznost & $25,0-29,9$ & Povećan \\
\hline Gojaznost klasa I & $30,0-34,9$ & Srednji \\
\hline Gojaznost klasa II & $35,0-39,9$ & Veliki \\
\hline Gojaznost klasa III & $>40,0$ & Veoma veliki \\
\hline
\end{tabular}

Ovo se odnosi na odrasle osobe, dok se kod dece i adolescenata koriste tabele sa percentilima (WHO, n.d.). Ovaj metod nije validan kada su u pitanju sportisti. Sportisti imaju veću mišićnu masu, a manji procenat masti, pa će se dobiti pogrešni rezultati (Weber et al., 2013). Ovaj metod ne razlikuje povećanje telesne mase koje se desilo na osnovu povećanja mišićne mase, ili sa druge strane masti (Taşcilar et al., 2011).

Metodom merenja obima struka se takođe može proceniti FM i uticaj na zdravlje. Merenja se najčešće vrše na sredini nadlaktice, sredini butine, na struku i kukovima. Prilikom merenja treba obratiti pažnju na tačno lociranje tačaka gde se vrši merenje, položaj merne trake $\left(90^{\circ}\right.$ u odnosu na uzdužnu osu trupa), da traka bude u kontaktu sa kožom, ali bez vršenja pritiska i da je očitavanje izvršeno u milimetrima (Lohman \& Roche, 1988).

Antropometrijske procedure izgledaju relativno jednostavne, ali ipak zahtevaju dobro obučenu osobu, da bi rezultati bili što validniji. Jeftine su, komforne za ispitanika i mogu se vršiti u terenskim uslovima.

\subsection{Hidrodenzitometrija (metoda podvodnog merenja)}

Ova metoda se još naziva i denzitometrija i bazirana je na Arhimedovim principima istiskivanja tečnosti. Predstavlja 2C model i jednu od najpreciznijih metoda u analizi sastava tela. Vrši se potapanjem kompletnog tela u vodu. Ispitanik treba da izdahne sav vazduh kada bude kompletno potopljen u vodu. Bazira se na merenju izbačene vode i korekcije rezidualnog volumena vazduha u plućima, da bi se dobila zapremina tela i računanjem mogla 
proceniti gustina tela i izračunati procent telesnih masti (\%BF). Kod osoba sa većom gustinom tela, manji je \%BF i obrnuto. Nije moguće imati uvid u distribuciju masnog tkiva (Borga et al., 2018). Osoba koja ima veći \%BF u telu, biće lakša u vodi od osobe sa većom mišićnom masom i malim procentom masti. Gustina FM $(0,9007 \mathrm{~g} / \mathrm{cm} 3)$ je manja od gustine vode, dok je FFM (1,1 g/cm3) veća (Brožek et al., 1963). Sama metoda zahteva obučenu osobu, posebnu opremu, skupa je, dugo traje i nije komforna za ispitanike. Nedostaci ove metode su povezani sa procenama zapremine tela i rezidualnog volumena pluća (Buskirk, 1961; Frank, 1969).

\subsection{Pletizmografija razmenom vazduha (ADP)}

ADP je metoda slična hidrodenzitometriji, koju je poslednjih godina počela da zamenjuje. Zastupljena je na $2 \mathrm{C}$ modelu. Merenje se vrši u zatvorenoj komori u kojoj ispitanik boravi, koja je odvojena membranom (dijafragmom) od referentne komore, koja se nalazi sa zadnje strane. Ulaskom ispitanika u komoru dolazi do promene zapremine vazduha, koja se može odrediti promenom pritiska i meri se zapremina tela, pa se na osnovu mase tela i zapremine tela mogu dobiti podaci o gustini tela, pa tako i FM i FFM. Ne može da se dobije distribucija masti i mišićne mase. Metoda je komforna, brza, jednostavna, ali skupa. Poznata je kao BOD POD, što je komercijalni proizvod (COSMED, Concord, California, USA). Rezultati mogu da odstupaju u zavisnosti od hidriranosti FFM, pa samim tim FM i FFM mogu biti potcenjeni, odnosno, precenjeni (Delisle-Houde et al., 2019; Kendall et al., 2017). Tačnost hidrodenzitometrije i pletizmografije je slična, u poređenju sa 4C metodom (Fields et al., 2001; Millard-Stafford et al., 2001).

\subsection{Dvostruko-energetska rendgenska denzitometrija (DXA)}

DXA se zasniva na propuštanju jonizujućih zraka, različitih energija, kroz telo ispitanika. Prilično je rasprostranjena tehnika i može se koristiti u svim uzrasnim kategorijama (Larsson et al., 1984). Spada u brze metode, ima malo zračenje i ne zahteva posebnu pripremu i tehničku obučenost. Propuštanjem dvostruko-energetskog jonizujućeg zračenja kroz telo, ili neke segmente, beleži se slabljenje, odnosno prigušenje signala, koje je posledica različite debljine tkiva, gustine i hemijskog sastava, kroz koje zraci prolaze. DXA metoda se može koristiti za određivanje FM, bezmasne mase tela i gustine minerala u kostima (Mazess et al., 1990). Primarno se koristi za određivanje gustine minerala u kostima i tu se smatra za gold-standard (Garg \& Kharb, 2013). Može se koristiti za analazu određenih delova tela, kao i za analizu sastava celog tela. Kod analize visceralnog masnog tkiva, u poređenju sa magnetnom rezonancom, DXA precenjuje visceralno masno tkivo kod gojaznih osoba (Neeland et al., 2016; Lemos \& Gallagher, 2017). Na slici dobijenom DXA skeniranjem se ne može odvojiti subkutano masno tkivo od visceralnog, već se u tom slučaju mora koristiti anatomski model koji predviđa debljinu subkutanog masnog tkiva. DXA-om se dobija dvodimenzionalna slika i nije moguće direktno odrediti zapreminu određenih delova, pa je potrebna upotreba anatomskih modela (Borga et al., 2018).

\subsection{Kompjuterizovana tomografija (CT) i magnetna rezonanca (MRI)}

CT i MRI su metode koje emitovanjem različite vrste i frekvencije zračenja daju slike visoke rezolucije u tri dimenzije. Ove metode se smatraju za gold standard, kada je u pitanju telesna analiza na nivou tkiva. Imaju mogućnost da prikažu i najmanje promene koje nastaju u telu (Prado \& Heymsfield, 2014). Mogu se raditi parcijalno, ili na celom telu. Kod CT se vrši propuštanje X zraka iz različitih uglova, da bi se dobila slika na osnovu slabljenja, ili prigušenja zraka, koje nastaje usled različite gustine tkiva (Addison et al., 2014), pa se dobije slika adipoznog tkiva, mekog tkiva, debljine i volumena. Kod MRI se koriste magnetna svojstva tela, odnosno gustina atoma vodonika (ponašaju se kao magnet pod pulsnim radiofrekventnim talasima) (Berger, 2002), da bi se dobila slika i odredila debljina i volumen adipoznog i mišićnog tkiva (Silver et al., 2010). Na osnovu ovoga, MRI je bezbednija metoda u odnosu na CT. Zbog velikog zračenja kod CT, praksa je da se rade snimci određene regije tela, da se ne radi skener celog tela. U poslednje vreme značajnu ulogu u identifikaciji masti u mišićima i jetri zauzima spektroskopska magnetna rezonanca, koja omogućuje uvid u metabolički rizik (Hwang \& Choi, 2015).

Prednosti ove dve metode kao najpreciznije, kada su u pitanju analize na nivou tkiva, su nedvosmislene, ali su skupe, zahtevaju obučeno osoblje, nisu lako dostupne i najveći nedostatak je izlaganje jonizujućem zračenju kod CT-a. Kod MRI može biti problem sa osobama koje imaju metalne implante. Sa druge strane, MRI se može koristiti kod dece, jer nema jonizijućeg zračenja. 


\subsection{Ultrazvuk (US)}

Manje poznata tehnika, pored već pomenutih koje se koriste u analizi telesnog sastava, je ultrazvuk. Većina ljudi je upoznata sa US kao dijagnostičkim uređajem, kada su u pitanju određeni zdravstveni problemi, ili trudnoća, ali je manje poznato da se US koristi u merenju masti i debljini skeletnih mišića (Smith-Ryan et al., 2014). Pomoću ovog uređaja se stvara ultrazvučna slika, kao rezultat cikličnih (zvučnih) talasa koji prolaze kroz kožu i od tkiva, masti i kostiju se delimično reflektuje nazad u vidu eha, u zavisnosti od promena akustičnog otpora kod tkiva (Wagner, 2013). Postoje dva režima moda ultrazvučne tehnologije, A (amplitudni mod) i B (mod osvetljenja). B-mod koristi frekvenciju od 1 do $10 \mathrm{MHz}$, dok A-mod koristi frekvenciju od 2,5 MHz i to su noviji komercijalni uređaji (Smith-Ryan et al., 2014). Kod dobijene ultrazvučne slike merenje debljine tkiva se vrši elektronskim kaliperom. Ova tehnika je dostupna, neinvazivna, brza i nema zračenja, ali nema dovoljno podataka o tačnosti metode, kada se uporedi sa nekom referentnom metodom, pa su potrebna dalja istraživanja. Interesovanje za analizu sastava tela US metodom je poraslo nakon razvoja portabilnih uređaja, kao što je Body-Metrix ultrazvučni sistem, primarno napravljen za korišćenje u fitnes industriji.

\subsection{Bioelektrična impedansa (BIA)}

BIA predstavlja jednu od najefektnijih, brzih, neinvazivnih, relativno jeftinih i validnih metoda analize telesnog sastava (Yu et al., 2010). Na tržištu je prisutan veliki broj uređaja, ali nisu svi validni. Validnost zavisi od kvaliteta uređaja, a oni su po pravilu skupi, ali i dalje značajno pristupačniji od prethodno navedenih metoda. Ovaj metod se pokazao kao dobar izbor i u upotrebi kod dece (Meredith-Jones et al., 2015). Danas na tržištu postoje multi-frekventni uređaji $(1,5,50,100,200,500,1000 \mathrm{kHz})$ i uređaji tačno određene frekvencije (400 $\mu \mathrm{A}$ i 50 kHz) (Kyle, Bosaeus, De Lorenzo, Deurenberg, Elia, Gómez et al., 2004). Razlika u merenjima između ova dva tipa uređaja je u većoj mogućnosti multi-frekventnih uređaja da vrše različita merenja, u različitim položajima, da daju rezultate za pojedine delove tela (Smith \& Madden, 2016). BIA je metod koji je baziran na telesnom otporu prilikom propuštanja struje niske jačine i određene frekvencije kroz ljudski organizam. Na električnu provodljivost utiče sadržaj vode i elektrolita u provodnicima. Veći otpor pružaju tkiva sa manjim sadržajem vode, a s obzirom da FFM sadrži skoro svu vodu i elektrolite, njegova provodljivost je daleko veća od FM. Putem savremenih BIA uređaja dobijaju se informacije o ukupnoj količini vode (TBW), intracelularnoj vodi, ekstracelularnoj vodi, količini minerala, mišića, masti (ukupne i visceralne), podaci o segmentnoj analizi (sva četiri ekstremiteta posebno i trup), vektorska analiza bioelektrične impedanse (BIVA) i informacije o faznom uglu (PA) celog tela. Fazni ugao tela se pokazao kao veoma važna varijabla i kod zdravih osoba je najčešće u opsegu između $5^{\circ}$ i $7^{\circ}$. Smatra se da govori o odnosu intra i ekstracelularne vode, odnosno o zdravlju ćelija, gde više vrednosti govore o boljoj funkciji ćelija. Fazni ugao je povezan sa fizičkom aktivnošću, polom (muškarci imaju više vrednosti zbog veće mišićne mase), uhranjenošću, inflamacijom, infekcijom (niže vrednosti faznog ugla) (Norman et al., 2012). Vrednosti faznog ugla mogu se predvideti za mnoge kliničke ishode i mortalitet kod osoba sa hroničnim bolestima (Iqbal, 2013). Detaljniji podaci o hidriranosti tkiva, varijaciji telesnih tečnosti, masi ćelija, kao i longitudinalnim promenama se dobijaju putem BIVA. BIVA daje kvalitativnu meru mekog tkiva, nevezano od veličine tela (Norman et al., 2012). Unutar 75. centila se nalaze zdrave osobe, dok se vrednosti iznad 95. smatraju abnormalnim (Walter-Kroker et al., 2011). BIVA pomaže u tumačenju promena telesne težine i telesnog sastava (Nicoletti et al., 2014). Pouzdanost BIA metode zavisi od kvaliteta uređaja, obučenosti osobe koja vrši analizu, tačno izmerene visine i težine, položaja ekstremiteta (ugao ekstremiteta od $30^{\circ}$ do $45^{\circ}$ u odnosu na telo), da ispitanik nije unosio hranu par sati pre analize, da mu je bešika prazna, da nije upražnjavao fizičku aktivnost, zavisi od faze menstrualnog ciklusa, trudnoće, metalnih ili silikonskih implanta, pejsmejkera (Yamaguchi et al., 2012; Kyle, Bosaeus, De Lorenzo, Deurenberg, Elia, Manuel Gómez et al., 2004), temperature u prostoriji $\left(24^{\circ}-34^{\circ} \mathrm{C}\right.$ ne utiče na rezultate merenja) (Caton et al., 1988; Garby et al., 1990). Kada dolazi do većih odstupanja u hidriranosti, rezultate FM i FFM treba tumačiti obazrivo, jer mogu biti precenjeni, ili podcenjeni (Mialich et al., 2014).

\section{ZAKLJUČAK}

Ovim mini preglednim radom je istaknut značaj analize telesnog sastava i najčešće korišćeni modeli i metode. Može se reći da do sada ne postoji univerzalna metoda kojom možemo dobiti sve validne podatke, već da je neophodno koristiti kombinaciju metoda (multi-komponentni model), da bi dobili validne rezultate. Najpristupačnije 
i metode koje imaju najširu primenu su antropometrija i BIA. Obe metode su pristupačne, neinvazivne, bezbedne za sve uzrasne kategorije, komforne za ispitanika, relativno brze i mogu se koristiti u terenskim uslovima (neki modeli BIA). Pored navedenog, antropometrija je još i jeftina metoda. Ostale navedene metode zahtevaju isključivo laboratorijske uslove, skupe su, nisu komforne za ispitanika, a neke od njih imaju veliko zračenje i najčešće se koriste u istraživačke svrhe. Sve pomenute metode zahtevaju dobro obučenu osobu koja ih sprovodi, uz neophodno poštovanje protokola.

Kako je antropometrija veoma pristupačna tehnika i u širokoj upotrebi, neophodno je da se u budućnosti razviju tehnike koje bi je učinile još preciznijom i pouzdanijom i omogućile segmentnu analizu telesnog sastava. Sa druge strane, BIA je sve popularnija metoda, ima sve širu primenu i u konstantnom je razvoju. Za dobijanje pouzdanih rezultata, preporuka je da se koriste naučno validirani uređaji, unapredi standardizacija protokola za merenje i definišu klinički prihvatljiva ograničenja u tačnosti.

Budući koncept analize telesnog sastava treba da ima za cilj da se dobijeni podaci posmatraju u celini, umesto da se posmatraju izolovano, da bi se objasnila veza između individualnih telesnih komponenti, organa i tkiva, njihove metaboličke i funkcionalne osobine i zdravstveni rizik.

\section{LITERATURA}

1. Addison, O., Marcus, R. L., Lastayo, P. C. \& Ryan, A. S. (2014). Intermuscular Fat: A Review of the Consequences and Causes. https://doi.org/10.1155/2014/309570

2. Berger, A. (2002). Magnetic resonance imaging. BMJ, 324(7328), 35. https://doi.org/10.1136/bmj.324.7328.35

3. Bhatt, G. C. (2016). Childhood Obesity as a Global Concern. J Child Obes, 1, 3-4. https://doi. org $/ 10.21767 / 2572-5394.100$

4. Borga, M., West, J., Bell, J. D., Harvey, N. C., Romu, T., Heymsfield, S. B. \& Leinhard, O. D. (2018). Advanced body composition assessment: From body mass index to body composition profiling. In Journal of Investigative Medicine (Vol. 66, Issue 5, pp. 887-895). BMJ Publishing Group. https://doi.org/10.1136/jim2018-000722

5. Brožek, J., Grande, F., Anderson, J. T. \& Keys, A. (1963). Densitometric analysis of body composition: revision of some quantitative assumptions. Annals of the New York Academy of Sciences, 110(1), 113-140. https://doi.org/10.1111/j.1749-6632.1963.tb17079.x

6. Buskirk, E. (1961). Underwater weighing and body density: a review of procedures. Acad. Sci. National Research Council Washington, DC, 90-105.

7. Caton, J. R., Molé, P. A., Adams, W. C. \& Heustis, D. S. (1988). Body composition analysis by bioelectrical impedance: Effect of skin temperature. Medicine and Science in Sports and Exercise, 20(5), 489-491. https:// doi.org/10.1249/00005768-198810000-00010

8. Delisle-Houde, P., Reid, R. E. R., Insogna, J. A., Prokop, N. W., Buchan, T. A., Fontaine, S. L. \& Andersen, R. E. (2019). Comparing DXA and air displacement plethysmography to assess body composition of male collegiate hockey players. Journal of Strength and Conditioning Research, 33(2), 474-478. https://doi. org/10.1519/JSC.0000000000001863

9. Durnin, J. V. G. A. \& Womersley, J. (1974). Body fat assessed from total body density and its estimation from skinfold thickness: measurements on 481 men and women aged from 16 to 72 Years. British Journal of Nutrition, 32(01), 77-97. https://doi.org/10.1079/bjn19740060

10. Ellis, K. J. (2000). Human body composition: In vivo methods. In Physiological Reviews (Vol. 80, Issue 2, pp. 649-680). American Physiological Society. https://doi.org/10.1152/physrev.2000.80.2.649

11. Fields, D. A., Wilson, G. D., Gladden, L. B., Hunter, G. R., Pascoe, D. D. \& Goran, M. I. (2001). Comparison of the BOD POD with the four-compartment model in adult females. Medicine and Science in Sports and Exercise, 33(9), 1605-1610. https://doi.org/10.1097/00005768-200109000-00026

12. Francis, P., Lyons, M., Piasecki, M., Mc Phee, J., Hind, K. \& Jakeman, P. (2017). Measurement of muscle health in aging. Biogerontology, 18(6), 901-911. https://doi.org/10.1007/s10522-017-9697-5

13. Frank, K. (1969). Practice curves and errors of measurement in estimating underwater weight by hydrostatic weighing. Med. Sci. Sports, 212-216. 
14. Garby, L., Lammert, O. \& Nielsen, E. (1990). Negligible effects of previous moderate physical activity and changes in environmental temperature on whole body electrical impedance. European Journal of Clinical Nutrition, 44(7), 545-546. http://www.ncbi.nlm.nih.gov/pubmed/2401285

15. Garg, M. \& Kharb, S. (2013). Dual energy X-ray absorptiometry: Pitfalls in measurement and interpretation of bone mineral density. Indian Journal of Endocrinology and Metabolism, 17(2), 203. https://doi. org/10.4103/2230-8210.109659

16. Hwang, J. H. \& Choi, C. S. (2015). Use of in vivo Magnetic resonance spectroscopy for studying metabolic diseases. In Experimental and Molecular Medicine (Vol. 47, Issue 2, p. e139). Nature Publishing Group. https://doi.org/10.1038/emm.2014.101

17. Iqbal, S. R. (2013). Physics of Bio-electrical Impedance Analysis: Phase Angle and its Application. Adv Life Sci Technol, 9, 4-12.

18. Jackson, A. S. \& Pollock, M. L. (1978). Generalized equations for predicting body density of men. British Journal of Nutrition, 40(3), 497-504. https://doi.org/10.1079/bjn19780152

19. Jackson, Andrew S., Pollock, M. L. \& Ward, A. (1980). Generalized equations for predicting body density of women. Medicine and Science in Sports and Exercise, 12(3), 175-182. https://doi.org/10.1249/00005768198023000-00009

20. Kendall, K. L., Fukuda, D. H., Hyde, P. N., Smith-Ryan, A. E., Moon, J. R. \& Stout, J. R. (2017). Estimating fat-free mass in elite-level male rowers: a four-compartment model validation of laboratory and field methods. Journal of Sports Sciences, 35(7), 624-633. https://doi.org/10.1080/02640414.2016.1183802

21. Kuriyan, R. (2018). Body composition techniques. Indian Journal of Medical Research, 148(5), 648-658. https://doi.org/10.4103/ijmr.IJMR_1777_18

22. Kyle, U. G., Bosaeus, I., De Lorenzo, A. D., Deurenberg, P., Elia, M., Gómez, J. M., Heitmann, B. L., KentSmith, L., Melchior, J. C., Pirlich, M., Scharfetter, H., Schols, A. M. W. J. \& Pichard, C. (2004). Bioelectrical impedance analysis - Part I: Review of principles and methods. Clinical Nutrition, 23(5), 1226-1243. https:// doi.org/10.1016/j.clnu.2004.06.004

23. Kyle, U. G., Bosaeus, I., De Lorenzo, A. D., Deurenberg, P., Elia, M., Manuel Gómez, J., Lilienthal Heitmann, B., Kent-Smith, L., Melchior, J. C., Pirlich, M., Scharfetter, H., Schols, A. M. W. J. \& Pichard, C. (2004). Bioelectrical impedance analysis - Part II: Utilization in clinical practice. Clinical Nutrition, 23, 1430-1453. https://doi.org/10.1016/j.clnu.2004.09.012

24. Larsson, B., Svardsudd, K. \& Welin, L. (1984). Abdominal adipose tissue distribution, obesity, and risk of cardiovascular disease and death: 13 year follow up of participants in the study of men born in 1913. British Medical Journal, 288(6428), 1401-1404. https://doi.org/10.1136/bmj.288.6428.1401

25. Lemos, T. \& Gallagher, D. (2017). Current body composition measurement techniques. Current Opinion in Endocrinology, Diabetes and Obesity, 24(5), 310-314. https://doi.org/10.1097/MED.0000000000000360

26. Lohman, T. \& Roche, A. (1988). Anthropometric Standardization Reference Manual. Human Kinetics.

27. Matiegka, J. (1921). The testing of physical efficiency. American Journal of Physical Anthropology, 4(3), 223230. https://doi.org/10.1002/ajpa.1330040302

28. Mazess, R. B., Barden, H. S., Bisek, J. P. \& Hanson, J. (1990). Dual-energy x-ray absorptiometry for totalbody and regional bone-mineral and soft-tissue compositionl'2. In Am J C/in Nuir (Vol. 5). https://academic. oup.com/ajcn/article-abstract/51/6/1106/4695297

29. Meredith-Jones, K. A., Williams, S. M. \& Taylor, R. W. (2015). Bioelectrical impedance as a measure of change in body composition in young children. Pediatric Obesity, 10(4), 252-259. https://oi.org/10.1111/ ijpo. 263

30. Mialich, M. S., Faccioli Sicchieri, J. M., Afonso, A., Junior, J. \& Sicchieri, J. M. F. (2014). 1-10Analysis of Body Composition: A Critical Review of the Use of Bioelectrical Impedance Analysis. International Journal of Clinical Nutrition, 2(1), 1-10. https://doi.org/10.12691/ijen-2-1-1

31. Millard-Stafford, M. L., Collins, M. A., Evans, E. M., Snow, T. K., Cureton, K. J. \& Rosskopf, L. B. (2001). Use of air displacement plethysmography for estimating body fat in a four-component model. Medicine and Science in Sports and Exercise, 33(8), 1311-1317. https://doi.org/10.1097/00005768-200108000-00011

32. Neeland, I. J., Grundy, S. M., Li, X., Adams-Huet, B. \& Vega, G. L. (2016). Comparison of visceral fat mass measurement by dual-X-ray absorptiometry and magnetic resonance imaging in a multiethnic cohort: the Dallas Heart Study. Nutrition \& Diabetes, 6(7), e221. https://doi.org/10.1038/nutd.2016.28 
33. Nicoletti, C. F., Camelo, J. S., Dos Santos, J. E., Marchini, J. S., Salgado, W. \& Nonino, C. B. (2014). Bioelectrical impedance vector analysis in obese women before and after bariatric surgery: Changes in body composition. Nutrition, 30(5), 569-574. https://doi.org/10.1016/j.nut.2013.10.013

34. Norman, K., Stobäus, N., Pirlich, M. \& Bosy-Westphal, A. (2012). Bioelectrical phase angle and impedance vector analysis - Clinical relevance and applicability of impedance parameters. In Clinical Nutrition (Vol. 31, Issue 6, pp. 854-861). Clin Nutr. https://doi.org/10.1016/j.clnu.2012.05.008

35. Peterson, S. J. \& Braunschweig, C. A. (2016). Prevalence of sarcopenia and associated outcomes in the clinical setting. In Nutrition in Clinical Practice (Vol. 31, Issue 1, pp. 40-48). SAGE Publications Inc. https:// doi.org/10.1177/0884533615622537

36. Prado, C. M. M. \& Heymsfield, S. B. (2014). Lean tissue imaging: A new era for nutritional assessment and intervention. Journal of Parenteral and Enteral Nutrition, 38(8), 940-953. https://doi. org/10.1177/0148607114550189

37. Rodríguez-Hernández, H., Simental-Mendía, L. E., Rodríguez-Ramírez, G. \& Reyes-Romero, M. A. (2013). Obesity and Inflammation: Epidemiology, Risk Factors, and Markers of Inflammation. International Journal of Endocrinology, 11. https://doi.org/10.1155/2013/678159

38. Silver, H. J., E. Brian Welch, M. J. Avison \& K. D. Niswender. (2010). Imaging body composition in obesity and weight loss: challenges and opportunities. Diabetes, Metabolic Syndrome and Obesity: Targets and Therapy, 3, 337. https://doi.org/10.2147/dmsott.s9454

39. Smith-Ryan, A. E., Fultz, S. N., Melvin, M. N., Wingfield, H. L. \& Woessner, M. N. (2014). Reproducibility and validity of A-mode ultrasound for body composition measurement and classification in overweight and obese men and women. PLoS ONE, 9(3). https://doi.org/10.1371/journal.pone.0091750

40. Smith, S. \& Madden, A. M. (2016). Body composition and functional assessment of nutritional status in adults: a narrative review of imaging, impedance, strength and functional techniques. Journal of Human Nutrition and Dietetics, 29(6), 714-732. https://doi.org/10.1111/jhn.12372

41. Taşcilar, E. M., Bilir, P., Akinci, A., Köse, K., Akçora, D., Inceoğlu, D. \& Fitöz, S. O. (2011). The Effect of Gonadotropin-Releasing Hormone Analog Treatment (Leuprolide) on Body Fat Distribution in Idiopathic Central Precocious Puberty. Turk J Pediatr, 53(1), 27-33.

42. Wagner, D. R. (2013). Ultrasound as a Tool to Assess Body Fat. Journal of Obesity, 2013. https://doi. org $/ 10.1155 / 2013 / 280713$

43. Walter-Kroker, A., Kroker, A., Mattiucci-Guehlke, M. \& Glaab, T. (2011). A practical guide to bioelectrical impedance analysis using the example of chronic obstructive pulmonary disease. In Nutrition Journal (Vol. 10, Issue 1). Nutr J. https://doi.org/10.1186/1475-2891-10-35

44. Wang, J., Thornton, J. C., Kolesnik, S. \& Pierson, R. N. (2000). Anthropometry in Body Composition An Overview. Ann N Y Acad Sci, 904, 317-326.

45. Wang, Z.M., Pierson, R. N. \& Heyms, S. B. (1992). The five-level model: a new approach to organizing bodycomposition research. The American Journal of Clinical Nutrition, 56(1), 19-28. https://academic.oup.com/ ajen/article-abstract/56/1/19/4715618

46. Weber, D. R., Moore, R. H., Leonard, M. B. \& Zemel, B. S. (2013). Fat and lean BMI reference curves in children and adolescents and their utility in identifying excess adiposity compared with BMI and percentage body fat. American Journal of Clinical Nutrition, 98(1), 49-56. https://doi.org/10.3945/ajcn.112.053611

47. WHO. (n.d.). WHO $\mid$ BMI-for-age (5-19 years). Retrieved June 18, 2020, from https://www.who.int/growthref/ who2007_bmi_for_age/en/

48. WHO. (2016). Obesity and overweight Fact sheet No 311.

49. WHO Expert Committee. (1995). Physical Status: The Use and Interpretation of Anthropometry.

50. Yamaguchi, C. M., Faintuch, J., Silva, M. M., Modolin, M., Hayashi, S. Y. \& Cecconello, I. (2012). Interference of silicone breast implants on bioimpedance measurement of body fat. Clinical Nutrition, 31(4), 574-576. https://doi.org/10.1016/j.clnu.2012.01.009

51. Yu, O.K., Rhee, Y.K., Park, T.S. \& Cha, Y.S. (2010). Comparisons of obesity assessments in over-weight elementary students using anthropometry, BIA, CT and DEXA. Nutrition Research and Practice, 4(2), 128. https://doi.org/10.4162/nrp.2010.4.2.128 


\title{
Review paper
}

\section{BODY COMPOSITION ANALYSIS: THE MOST COMMON TEST MODELS AND RESEARCH METHODS ${ }^{1}$}

\author{
UDC: 796:61 \\ 616-071.3 \\ https://doi.org/10.18485/snip.2021.11.1.en.5 \\ Dragan Đurđević \\ Faculty of Medicine, Department of Sports Medicine, University of Belgrade, Serbia ${ }^{3}$
}

\begin{abstract}
Accurate and valid analysis of body composition is important for the diagnosis of nutritional status, training impact assessment, the body's response to nutritional and therapeutic interventions, growth and development of the organism, and health risk assessment. With the increasing prevalence of chronic non-communicable diseases, obesity, the need for different models and methods of body composition analysis has also increased. This review paper aimed to show the most commonly used methods for body composition analysis and to give a brief insight into the current techniques. The methods for analysing body composition vary in their accuracy and reliability and in practice the use of appropriate methods depends on the interest and the required accuracy, e.g. dual-energy X-ray absoptiometry (DXA) as the gold standard for determining bone mineral density, or magnetic resonance imaging (MRI) as the gold standard for soft tissue and organ analysis. These methods, along with computed tomography (CT), hydrodensitometry and plethysmography, are routinely used in clinical medicine, and due to their complexity, availability and high prices, they are mostly used in sports medicine for research purposes. In sports medicine, the anthropometric method and bioelectrical impedance analysis (BIA) are mostly used, due to their simplicity and comfort for the examinees. The best assessment of body composition can be obtained by a combination of several methods - a multi-component model, which can increase the accuracy and reliability of the obtained data, and health risk can be assessed with greater certainty.
\end{abstract}

Key words: body composition, nutritional status, anthropometry, DXA, BIA, sports medicine

\section{INTRODUCTION}

Body composition analysis (BCA) falls into the domain of interest of sports experts, nutritionists and health professionals. Accurate and valid assessment of nutritional status, morphological and functional capacities has a significant role in assessing the impact of training and achieving top results of an athlete, it enables monitoring the body's response to nutritional and therapeutic interventions, growth and development, and intrinsic and extrinsic factors at different biological levels. With the increasing prevalence of chronic non-communicable diseases, obesity, the need for different models and methods of body composition analysis has also increased, in order to objectively assess the nutritional status, functional capacity, health risk and morbidity. Primarily, the interest in body composition analysis arose so as to determine body fat mass (FM). Technological development and better understanding of body composition analysis and impact on health led to new opportunities to improve current practice.

In addition to the above, body composition analysis also provides information to help identify and assess cachexia, sarcopenia, and obesity. Cachexia is a condition characterized by a loss of adipose tissue and muscle

\footnotetext{
Paper received: 21 June 2020, edited: 7 July 2020, accepted for publication: 7 July 2020

$\triangle$ d_djurdjevic@yahoo.com

Dragan Đurđević is a PhD student at the Faculty of Medicine, University of Belgrade.
} 
mass, which is the result of a number of conditions, and is most often caused by advanced aging or malignant diseases. Sarcopenia is a loss of muscle mass caused by aging, while obesity is a chronic disease, characterized by excessive accumulation of body fat, which leads to numerous health complications: hypertension, type 2 diabetes mellitus, metabolic syndrome, heart and blood vessel diseases, spine and joint diseases, mental disorders (Bhatt, 2016; Rodríguez-Hernández et al., 2013). Obesity is one of the biggest health problems in the world and can be said to take the form of a pandemic. In addition to adults, it is concerning that it is increasingly common in children. All of this is associated with decreased functional abilities, increased morbidity, and mortality (Francis et al., 2017; Peterson \& Braunschweig, 2016). The World Health Organization (WHO) data indicates that in 2014, there were 600 million adults and 42 million children under the age of 5 who were overweight (WHO, 2016). This tells us how important it is to identify and use valid methods and models in body composition analysis.

\section{MODELS AND METHODS OF BODY COMPOSITION ANALYSIS}

\section{Models}

Body composition analysis can be done by direct and indirect measurement. Despite the fact that direct measurement is the most accurate method, since it requires tissue dissection, it is not an option for use. There are different models and techniques for indirect measurement.

The most widely used and basic model for body composition analysis is the two-component model (2C), where the body is divided into two parts, fat (FM) and fat-free mass (FFM). The $2 \mathrm{C}$ model is based on determining body density and the most commonly used technique is hydrodensitometry. In addition to the $2 \mathrm{C}$ model, there is a three-component model (3C), where FFM is divided into two parts, the water content and solids, which consists predominantly of proteins and minerals. The next model, which theoretically gives more valid results than the $3 \mathrm{C}$ model, is the four-component $(4 \mathrm{C})$ model, which provides body analysis results for fats, minerals, total body water (TBW), and proteins. In addition to the results obtained by hydrodensitometry, it is necessary to additionally use dual-energy X-ray absorptiometry (DXA) to obtain accurate data on bone mineral values, and neutron activation analysis to obtain accurate protein data. Based on the above, it is clear that additional measurements expand the number of tested components in BCA (e.g. the amount of calcium, phosphorus, nitrogen, determining extracellular water) and that it is necessary that the measurement is entirely based on independent results for the given component, to reach the multi-component model (MCM) of body analysis, which provides a large amount of data but requires a combination of different measurement methods (Ellis, 2000; Kuriyan, 2018).

Following the development of the model over time, Wang et al. have combined and presented a model of five levels of body composition, which has become the standard in the BCA research (Wang et al., 1992).

\subsection{Five levels of body composition}

Current body composition analysis models relate to five levels of body composition. The first one is the atomic level, which contains the main chemical elements (oxygen, carbon, hydrogen, nitrogen, calcium and phosphorus), and whose analysis can provide very important information, such as nitrogen content, which tells us about the total amount of protein in the body, and is determined by neutron activation analysis. The second level consists of the main molecular parts and that is the molecular level, which includes water, proteins, carbohydrates, fats and minerals in bones and soft tissues. For example, essential fats are very important for the cell membrane function. While water and minerals in bones can be determined directly (isotope dilution, DXA), the rest is assessed indirectly. The third level is cellular, which consists of cell mass (fat and fat-free cell mass, where metabolic processes take place), extracellular fluid and extracellular matrix. Attempts have been made to develop certain models, based on anthropometry, for estimating cell mass, but none are in widespread use. The fourth is the tissue-organic level, which consists of tissues, organs and systems. For example, adipose tissue's location is subcutaneous and internal or visceral. It is assessed by indirect methods (e.g. ultrasound, CT). The last level represents the level of the whole body, i.e. the organism as a whole, which is divided into different parts and where it is necessary to use different models and methods of body composition analysis - the multi-component model (WHO Expert Committee, 1995). 


\section{Methods}

\subsection{Anthropometric measurements}

Anthropometry is a widely used method of measuring body mass, longitudinal skeletal dimensionality, transverse skeletal dimensionality, circumference and thickness of skin folds (SF), especially in the child population. Anthropometric measurements can simply help determine the development of the body, morphological characteristics, nutritional status, the relationship between FM and FFM, the impact of training and nutrition on the body, nutritional interventions, and health risks.

As early as in 1921, an equation was developed for estimating body fat based on anthropometric measurements, by measuring the thickness of skin folds (Matiegka, 1921). By measuring the thickness of the skin folds with a calliper, measures are obtained by which, through the use of equations, FM and FFM are estimated. Based on the most commonly used equations, it is mostly measured at the following ten points: triceps, subscapular, abdominal, suprailiac, thigh, biceps, calf, chest, umbilicus, thorax (J. Wang et al., 2000). In order to obtain precise measurements, it is necessary to use a well-calibrated calliper (e.g. Lange, Holtain) and, as mentioned, well-trained personnel to conduct the procedure in line with the standardized methodology. Special attention should be paid to precisely locating the points, pulling of the skin and placing the instrument at an angle of $90^{\circ}$. The most commonly used equations for determining FM and FFM based on the measures obtained by the SF measurement are Jackson and Pollock (Jackson \& Pollock, 1978; Jackson et al., 1980) and Durnin and Vomersley (Durnin \& Vomersley, 1974).

Using anthropometric procedures, as mentioned, it is also possible to determine nutritional status by calculating body mass index (BMI), and this is the most commonly used measure for determining overweight and obesity. The examinees' body weight (BW) and body height (BH) are measured, and then the BMI is calculated based on a mathematical formula:

$\mathrm{BMI}=\mathrm{BW}(\mathrm{kg}) / \mathrm{BH}\left(\mathrm{m}^{2}\right)$

Based on the classification made by the World Health Organization (WHO), a person's nutritional status and health risk are determined (Table 1).

Table 1. WHO BMI classification

\begin{tabular}{lcc}
\hline Classification & BMI $\left(\mathrm{kg} / \mathrm{m}^{2}\right)$ & Risk of comorbidities \\
\hline Underweight & $<18,5$ & Low (other health risks) \\
\hline Normal range & $18,5-24,9$ & Average \\
\hline Overweight & $>25$ & \\
\hline Pre-obese & $25,0-29,9$ & Increased \\
\hline Obese class I & $30,0-34,9$ & Moderate \\
\hline Obese class II & $35,0-39,9$ & Severe \\
\hline Obese class III & $>40,0$ & Very severe \\
\hline
\end{tabular}

This applies to adults, while percentile tables are used for children and adolescents (WHO, n.d.). This method is not valid when it comes to athletes. Athletes have more muscle mass and a lower percentage of fat, so wrong results will be obtained (Weber et al., 2013). This method does not differentiate between weight gain based on an increase in muscle mass, or that based on fat increase (Taşcilar et al., 2011).

Waist circumference can also be used to assess FM and health effects. Measurements are most often performed in the middle of the upper arm, the middle of the thigh, the waist and the hips. When measuring, attention must be paid to the exact location of the measuring points, the position of the measuring tape $\left(90^{\circ}\right.$ in relation to the longitudinal axis of the trunk), that the tape is in contact with the skin, but without pressure and that the reading is made in millimetres (Lohman \& Roche, 1988).

Anthropometric procedures seem relatively simple, but still require a well-trained person, in order for the results to be as valid as possible. They are cheap, comfortable for the participants and can be performed on-field.

\subsection{Hydrodensitometry (hydrostatic/underwater weighing)}

This method is also called densitometry and is based on Archimedes' principles of buoyancy. It represents the $2 \mathrm{C}$ model and one of the most accurate methods in the analysis of body composition. It is conducted by immersing 
the entire body in water. The subject should exhale all air when completely submerged in water. It is based on the measurement of water that the body displaces and the correction of the residual volume, in order to obtain the volume of the body and to calculate the density of the body and body fat percentage (\% BF). In people with higher body density, the $\% \mathrm{BF}$ is lower and vice versa. It is not possible to have insight into adipose tissue distribution (Borga et al., 2018). A person with higher \%BF will be lighter in water than a person with higher muscle mass and lower \%BF. The density of FM $(0.9007 \mathrm{~g} / \mathrm{cm} 3)$ is lower than the density of water, while the FFM $(1.1 \mathrm{~g} / \mathrm{cm} 3)$ is higher (Brožek et al., 1963). The method itself requires a trained person, special equipment, it is expensive, takes a long time and is not comfortable for the participants. The disadvantages of this method are related to estimates of body volume and residual volume (Buskirk, 1961; Frank, 1969).

\subsection{Air displacement plethysmography (ADP)}

ADP is a method similar to hydrodensitometry, which it has begun to replace in recent years. It represents a $2 \mathrm{C}$ model. The measurement is performed in a closed chamber where the participant sits, which is separated by a membrane (diaphragm) from the reference chamber, which is located on the back. When the subject enters the chamber, there is a change in the air volume, which can be determined by changing the pressure and measuring body volume, so based on body weight and body volume, data on body density can be obtained, including FM and FFM. The distribution of fat and muscle mass cannot be obtained. The method is comfortable, fast, simple, but expensive. It is known as BOD POD, which is a commercial product (COSMED, Concord, California, USA). The results may vary depending on the hydration of the FFM, and therefore the FM and FFM may be underestimated or overestimated (Delisle-Houde et al., 2019; Kendall et al., 2017). The accuracy of hydrodensitometry and ADP is similar, compared to the 4C method (Fields et al., 2001; Millard-Stafford et al., 2001).

\subsection{Dual-energy X-ray absorptiometry (DXA)}

DXA is based on the transmission of ionizing rays of different energies through the examinee's body. It is a fairly common technique and can be used in all age categories (Larsson et al., 1984). It belongs to the fast methods, it involves low radiation and does not require special preparation and technical training. By passing dual-energy ionizing radiation through the body, or some of its segments, the attenuation of the signal is recorded, which is a consequence of different tissue thickness, density and chemical composition through which the rays pass. The DXA method can be used to determine FM, lean body mass, and bone mineral density (Mazess et al., 1990). It is primarily used to determine the density of minerals in bones and is considered the gold standard (Garg \& Kharb, 2013). It can be used for the analysis of certain parts of the body, as well as for the analysis of the composition of the whole body. In visceral adipose tissue analysis, compared to magnetic resonance imaging, DXA overestimates visceral adipose tissue in obese individuals (Neeland et al., 2016; Lemos \& Gallagher, 2017). In the image obtained by DXA scanning, subcutaneous adipose tissue cannot be separated from visceral, but in that case an anatomical model predicting the thickness of subcutaneous adipose tissue must be used. DXA provides a two-dimensional image and it is not possible to directly determine the volume of certain parts, so the use of anatomical models is required (Borga et al., 2018).

\subsection{Computed tomography (CT) and magnetic resonance imaging (MRI)}

CT and MRI are methods that, by emitting different types and frequencies of radiation, provide highresolution images in three dimensions. These methods are considered the gold standard, when it comes to body analysis at the tissue level. They have the ability to show even the smallest changes that occur in the body (Prado \& Heymsfield, 2014). They can be conducted partially, or on the whole body. In CT, X-rays are transmitted from different angles, in order to obtain an image based on the attenuation of rays, which occurs due to different tissue densities (Addison et al., 2014), so an image of adipose tissue, soft tissue, thickness and volume is obtained. MRI uses the magnetic properties of the body, i.e. the density of hydrogen atoms (they act as a magnet under pulsed radio frequency waves) (Berger, 2002), in order to obtain an image and determine the thickness and volume of adipose and muscle tissue (Silver et al., 2010). Based on this, MRI is a safer method than CT. Due to the high radiation in $\mathrm{CT}$, the practice is to take images of a certain region of the body, not to scan the entire body. Recently, spectroscopic magnetic resonance imaging has played a significant role in the identification of muscle and liver fat, which provides insight into metabolic risks (Hwang \& Choi, 2015). 
The advantages of these two methods as the most accurate, when it comes to tissue level analysis, are unequivocal, but they are expensive, require trained personnel, they are not easily available and the major disadvantage is the exposure to ionizing radiation in CT. MRI can be a problem for people who have metal implants. On the other hand, MRI can be used in children, because there is no ionizing radiation.

\subsection{Ultrasound (US)}

A less known technique, in addition to the already mentioned ones in the analysis of body composition, is ultrasound. Most people are familiar with the US as a diagnostic device when it comes to certain health problems or pregnancy, but it is less known that the US is used to measure fat and skeletal muscle thickness (Smith-Ryan et al., 2014). This device creates an ultrasound image, as a result of sound waves that pass through the skin and partially reflect back from tissues, fat and bones in the form of echoes, depending on changes in acoustic resistance in tissue (Wagner, 2013). There are two modes of ultrasound technology, A (amplitude mode) and B (brightness mode). B-mode uses a frequency of 1-10 MHz, while A-mode uses a frequency of $2.5 \mathrm{MHz}$ and these are newer commercial devices (Smith-Ryan et al., 2014). In the obtained ultrasound image, the thickness of the tissue is measured with an electronic calliper. This technique is accessible, non-invasive, fast and there is no radiation, but there is not enough data on the accuracy, when compared to the reference method, so further research is needed. Interest in the analysis of body composition by the US method has grown after the development of portable devices, such as the BodyMetrix ultrasound system, primarily made for use in the fitness industry.

\subsection{Bioelectric Impedance Analysis (BIA)}

BIA is one of the most effective, fastest, non-invasive, relatively low-cost and valid methods of body composition analysis (Yu et al., 2010). There are a large number of devices on the market, but not all of them are valid. Their validity depends on the quality of the devices, and they are usually expensive, but still significantly more affordable than the previously mentioned methods. This method has also been shown to be a good choice for use in children (Meredith-Jones et al., 2015). There are multi-frequency devices $(1,5,50,100,200,500,1000 \mathrm{kHz}$ ) and single frequency devices $(400 \mu \mathrm{A}$ and $50 \mathrm{kHz}$ ) on the market today (Kyle, Bosaeus, De Lorenzo, Deurenberg, Elia, Gómez, et al., 2004). The difference in measurements between these two types of devices is in the greater ability of multi-frequency devices to perform different measurements, in different positions, to give results for individual body parts (Smith \& Madden, 2016). BIA is a method that is based on the body's resistance when passing a very low electric current and a certain frequency through the human body. Electrical conductivity is affected by the water and electrolyte content of the conductors. Higher resistance is provided by tissues with lower water content, and since FFM contains almost all water and electrolytes, its conductivity is far higher than FM. Modern BIA devices provide information on the total amount of water (TBW), intracellular water, extracellular water, the amount of minerals, muscles, fats (total and visceral), as well as data on segmental analysis (all four extremities separately and the trunk), bioelectrical impedance vector analysis (BIVA) and the phase angle (PA) of the whole body. The phase angle of the body has proven to be a very important variable and in healthy individuals it is usually in the range between $5^{\circ}$ and $7^{\circ}$. It is considered to show the ratio of intra and extracellular water, that is, of cell health, where higher values indicate better cell function. The phase angle is associated with physical activity, gender (men have higher values due to higher muscle mass), nutrition, inflammation, infection (lower phase angle values) (Norman et al., 2012). Phase angle values can be predictive for many clinical outcomes and mortality in people with chronic diseases (Iqbal, 2013). More detailed data on tissue hydration, body fluid variation, cell mass, as well as longitudinal changes are obtained via BIVA. BIVA provides a qualitative measure of soft tissue, regardless of body size (Norman et al., 2012). Within the 75th percentile are healthy individuals, while values above the 95th are considered abnormal (Walter-Kroker et al., 2011). BIVA helps to interpret changes in body weight and body composition (Nicoletti et al., 2014). The reliability of the BIA method depends on the quality of the device, a well-trained personnel conducting the analysis, accurately measured height and weight, limb position (limb angle of $30^{\circ}-45^{\circ}$ in relation to the body), that the examinee did not eat a few hours before analysis, that the bladder is empty, that the examinee did not exercise, phase of the menstrual cycle, pregnancy, metal or silicone implants, pacemaker (Yamaguchi et al., 2012; Kyle, Bosaeus, De Lorenzo, Deurenberg, Elia, Manuel Gómez, et al., 2004), indoor temperature $\left(24^{\circ}-34^{\circ} \mathrm{C}\right.$ does not affect measurement results) (Caton et al., 1988; Garby et al., 1990). When there are larger deviations in hydration, the results of FM and FFM should be interpreted carefully, because they can be overestimated or underestimated (Mialich et al., 2014). 


\section{CONCLUSION}

This mini-review paper highlights the importance of body composition analysis and the most commonly used models and methods. It can be said that so far there is no universal method that can be used to obtain all valid data, but it is necessary to use a combination of methods (multi-component model), in order to obtain valid results. The most accessible and widely used methods are anthropometry and BIA. Both methods are affordable, non-invasive, safe for all age categories, comfortable for the examinee, relatively fast and can be used on-field (some BIA models). In addition to the above, anthropometry is also a cheap method. The other mentioned methods require exclusively laboratory conditions, they are expensive and less comfortable for the examinee, and some of them involve a lot of radiation and they are most frequently used for research purposes. All the mentioned methods require a well-trained personnel to conduct them, with the necessary adherence to the protocol.

As anthropometry is a very accessible and widely used technique, it is necessary to develop techniques in the future that would make it even more precise and reliable and enable segmental analysis of body composition. On the other hand, BIA is an increasingly popular method, it has a wider application and is in constant development. To obtain reliable results, it is recommended to use scientifically validated devices, improve the standardization of measurement protocols and define clinically acceptable limitations in terms of accuracy.

The future concept of body composition analysis should aim to look at the data as a whole, rather than in isolation, to explain the relationship between individual body components, organs and tissues, their metabolic and functional properties, and health risks.

\section{REFERENCES}

1. Addison, O., Marcus, R. L., Lastayo, P. C. \& Ryan, A. S. (2014). Intermuscular Fat: A Review of the Consequences and Causes. https://doi.org/10.1155/2014/309570

2. Berger, A. (2002). Magnetic resonance imaging. BMJ, 324(7328), 35. https://doi.org/10.1136/bmj.324.7328.35

3. Bhatt, G. C. (2016). Childhood Obesity as a Global Concern. J Child Obes, 1, 3-4. https://doi. org $/ 10.21767 / 2572-5394.100$

4. Borga, M., West, J., Bell, J. D., Harvey, N. C., Romu, T., Heymsfield, S. B. \& Leinhard, O. D. (2018). Advanced body composition assessment: From body mass index to body composition profiling. In Journal of Investigative Medicine (Vol. 66, Issue 5, pp. 887-895). BMJ Publishing Group. https://doi.org/10.1136/jim2018-000722

5. Brožek, J., Grande, F., Anderson, J. T. \& Keys, A. (1963). Densitometric analysis of body composition: revision of some quantitative assumptions. Annals of the New York Academy of Sciences, 110(1), 113-140. https://doi.org/10.1111/j.1749-6632.1963.tb17079.x

6. Buskirk, E. (1961). Underwater weighing and body density: a review of procedures. Acad. Sci. National Research Council Washington, DC, 90-105.

7. Caton, J. R., Molé, P. A., Adams, W. C. \& Heustis, D. S. (1988). Body composition analysis by bioelectrical impedance: Effect of skin temperature. Medicine and Science in Sports and Exercise, 20(5), 489-491. https:// doi.org/10.1249/00005768-198810000-00010

8. Delisle-Houde, P., Reid, R. E. R., Insogna, J. A., Prokop, N. W., Buchan, T. A., Fontaine, S. L. \& Andersen, R. E. (2019). Comparing DXA and air displacement plethysmography to assess body composition of male collegiate hockey players. Journal of Strength and Conditioning Research, 33(2), 474-478. https://doi. org/10.1519/JSC.0000000000001863

9. Durnin, J. V. G. A. \& Womersley, J. (1974). Body fat assessed from total body density and its estimation from skinfold thickness: measurements on 481 men and women aged from 16 to 72 Years. British Journal of Nutrition, 32(01), 77-97. https://doi.org/10.1079/bjn19740060

10. Ellis, K. J. (2000). Human body composition: In vivo methods. In Physiological Reviews (Vol. 80, Issue 2, pp. 649-680). American Physiological Society. https://doi.org/10.1152/physrev.2000.80.2.649

11. Fields, D. A., Wilson, G. D., Gladden, L. B., Hunter, G. R., Pascoe, D. D. \& Goran, M. I. (2001). Comparison of the BOD POD with the four-compartment model in adult females. Medicine and Science in Sports and Exercise, 33(9), 1605-1610. https://doi.org/10.1097/00005768-200109000-00026 
12. Francis, P., Lyons, M., Piasecki, M., Mc Phee, J., Hind, K. \& Jakeman, P. (2017). Measurement of muscle health in aging. Biogerontology, 18(6), 901-911. https://doi.org/10.1007/s10522-017-9697-5

13. Frank, K. (1969). Practice curves and errors of measurement in estimating underwater weight by hydrostatic weighing. Med. Sci. Sports, 212-216.

14. Garby, L., Lammert, O. \& Nielsen, E. (1990). Negligible effects of previous moderate physical activity and changes in environmental temperature on whole body electrical impedance. European Journal of Clinical Nutrition, 44(7), 545-546. http://www.ncbi.nlm.nih.gov/pubmed/2401285

15. Garg, M. \& Kharb, S. (2013). Dual energy X-ray absorptiometry: Pitfalls in measurement and interpretation of bone mineral density. Indian Journal of Endocrinology and Metabolism, 17(2), 203. https://doi. org $/ 10.4103 / 2230-8210.109659$

16. Hwang, J. H. \& Choi, C. S. (2015). Use of in vivo Magnetic resonance spectroscopy for studying metabolic diseases. In Experimental and Molecular Medicine (Vol. 47, Issue 2, p. e139). Nature Publishing Group. https://doi.org/10.1038/emm.2014.101

17. Iqbal, S. R. (2013). Physics of Bio-electrical Impedance Analysis: Phase Angle and its Application. Adv Life Sci Technol, 9, 4-12.

18. Jackson, A. S. \& Pollock, M. L. (1978). Generalized equations for predicting body density of men. British Journal of Nutrition, 40(3), 497-504. https://doi.org/10.1079/bjn19780152

19. Jackson, Andrew S., Pollock, M. L. \& Ward, A. (1980). Generalized equations for predicting body density of women. Medicine and Science in Sports and Exercise, 12(3), 175-182. https://doi.org/10.1249/00005768198023000-00009

20. Kendall, K. L., Fukuda, D. H., Hyde, P. N., Smith-Ryan, A. E., Moon, J. R. \& Stout, J. R. (2017). Estimating fat-free mass in elite-level male rowers: a four-compartment model validation of laboratory and field methods. Journal of Sports Sciences, 35(7), 624-633. https://doi.org/10.1080/02640414.2016.1183802

21. Kuriyan, R. (2018). Body composition techniques. Indian Journal of Medical Research, 148(5), 648-658. https://doi.org/10.4103/ijmr.IJMR_1777_18

22. Kyle, U. G., Bosaeus, I., De Lorenzo, A. D., Deurenberg, P., Elia, M., Gómez, J. M., Heitmann, B. L., KentSmith, L., Melchior, J. C., Pirlich, M., Scharfetter, H., Schols, A. M. W. J. \& Pichard, C. (2004). Bioelectrical impedance analysis - Part I: Review of principles and methods. Clinical Nutrition, 23(5), 1226-1243. https:// doi.org/10.1016/j.clnu.2004.06.004

23. Kyle, U. G., Bosaeus, I., De Lorenzo, A. D., Deurenberg, P., Elia, M., Manuel Gómez, J., Lilienthal Heitmann, B., Kent-Smith, L., Melchior, J. C., Pirlich, M., Scharfetter, H., Schols, A. M. W. J. \& Pichard, C. (2004). Bioelectrical impedance analysis - Part II: Utilization in clinical practice. Clinical Nutrition, 23, 1430-1453. https://doi.org/10.1016/j.clnu.2004.09.012

24. Larsson, B., Svardsudd, K. \& Welin, L. (1984). Abdominal adipose tissue distribution, obesity, and risk of cardiovascular disease and death: 13 year follow up of participants in the study of men born in 1913. British Medical Journal, 288(6428), 1401-1404. https://doi.org/10.1136/bmj.288.6428.1401

25. Lemos, T. \& Gallagher, D. (2017). Current body composition measurement techniques. Current Opinion in Endocrinology, Diabetes and Obesity, 24(5), 310-314. https://doi.org/10.1097/MED.0000000000000360

26. Lohman, T. \& Roche, A. (1988). Anthropometric Standardization Reference Manual. Human Kinetics.

27. Matiegka, J. (1921). The testing of physical efficiency. American Journal of Physical Anthropology, 4(3), 223230. https://doi.org/10.1002/ajpa.1330040302

28. Mazess, R. B., Barden, H. S., Bisek, J. P. \& Hanson, J. (1990). Dual-energy x-ray absorptiometry for totalbody and regional bone-mineral and soft-tissue compositionl'2. In Am J C/in Nuir (Vol. 5). https://academic. oup.com/ajcn/article-abstract/51/6/1106/4695297

29. Meredith-Jones, K. A., Williams, S. M. \& Taylor, R. W. (2015). Bioelectrical impedance as a measure of change in body composition in young children. Pediatric Obesity, 10(4), 252-259. https://doi.org/10.1111/ ijpo.263

30. Mialich, M. S., Faccioli Sicchieri, J. M., Afonso, A., Junior, J. \& Sicchieri, J. M. F. (2014). 1-10Analysis of Body Composition: A Critical Review of the Use of Bioelectrical Impedance Analysis. International Journal of Clinical Nutrition, 2(1), 1-10. https://doi.org/10.12691/ijcn-2-1-1

31. Millard-Stafford, M. L., Collins, M. A., Evans, E. M., Snow, T. K., Cureton, K. J. \& Rosskopf, L. B. (2001). Use of air displacement plethysmography for estimating body fat in a four-component model. Medicine and Science in Sports and Exercise, 33(8), 1311-1317. https://doi.org/10.1097/00005768-200108000-00011 
32. Neeland, I. J., Grundy, S. M., Li, X., Adams-Huet, B. \& Vega, G. L. (2016). Comparison of visceral fat mass measurement by dual-X-ray absorptiometry and magnetic resonance imaging in a multiethnic cohort: the Dallas Heart Study. Nutrition \& Diabetes, 6(7), e221. https://doi.org/10.1038/nutd.2016.28

33. Nicoletti, C. F., Camelo, J. S., Dos Santos, J. E., Marchini, J. S., Salgado, W. \& Nonino, C. B. (2014). Bioelectrical impedance vector analysis in obese women before and after bariatric surgery: Changes in body composition. Nutrition, 30(5), 569-574. https://doi.org/10.1016/j.nut.2013.10.013

34. Norman, K., Stobäus, N., Pirlich, M. \& Bosy-Westphal, A. (2012). Bioelectrical phase angle and impedance vector analysis - Clinical relevance and applicability of impedance parameters. In Clinical Nutrition (Vol. 31, Issue 6, pp. 854-861). Clin Nutr. https://doi.org/10.1016/j.clnu.2012.05.008

35. Peterson, S. J. \& Braunschweig, C. A. (2016). Prevalence of sarcopenia and associated outcomes in the clinical setting. In Nutrition in Clinical Practice (Vol. 31, Issue 1, pp. 40-48). SAGE Publications Inc. https:// doi.org $/ 10.1177 / 0884533615622537$

36. Prado, C. M. M. \& Heymsfield, S. B. (2014). Lean tissue imaging: A new era for nutritional assessment and intervention. Journal of Parenteral and Enteral Nutrition, 38(8), 940-953. https://doi. org/10.1177/0148607114550189

37. Rodríguez-Hernández, H., Simental-Mendía, L. E., Rodríguez-Ramírez, G. \& Reyes-Romero, M. A. (2013). Obesity and Inflammation: Epidemiology, Risk Factors, and Markers of Inflammation. International Journal of Endocrinology, 11. https://doi.org/10.1155/2013/678159

38. Silver, H. J., E. Brian Welch, M. J. Avison \& K. D. Niswender. (2010). Imaging body composition in obesity and weight loss: challenges and opportunities. Diabetes, Metabolic Syndrome and Obesity: Targets and Therapy, 3, 337. https://doi.org/10.2147/dmsott.s9454

39. Smith-Ryan, A. E., Fultz, S. N., Melvin, M. N., Wingfield, H. L. \& Woessner, M. N. (2014). Reproducibility and validity of A-mode ultrasound for body composition measurement and classification in overweight and obese men and women. PLoS ONE, 9(3). https://doi.org/10.1371/journal.pone.0091750

40. Smith, S. \& Madden, A. M. (2016). Body composition and functional assessment of nutritional status in adults: a narrative review of imaging, impedance, strength and functional techniques. Journal of Human Nutrition and Dietetics, 29(6), 714-732. https://doi.org/10.1111/jhn.12372

41. Taşcilar, E. M., Bilir, P., Akinci, A., Köse, K., Akçora, D., Inceoğlu, D. \& Fitöz, S. O. (2011). The Effect of Gonadotropin-Releasing Hormone Analog Treatment (Leuprolide) on Body Fat Distribution in Idiopathic Central Precocious Puberty. Turk J Pediatr, 53(1), 27-33.

42. Wagner, D. R. (2013). Ultrasound as a Tool to Assess Body Fat. Journal of Obesity, 2013. https://doi. org $/ 10.1155 / 2013 / 280713$

43. Walter-Kroker, A., Kroker, A., Mattiucci-Guehlke, M. \& Glaab, T. (2011). A practical guide to bioelectrical impedance analysis using the example of chronic obstructive pulmonary disease. In Nutrition Journal (Vol. 10, Issue 1). Nutr J. https://doi.org/10.1186/1475-2891-10-35

44. Wang, J., Thornton, J. C., Kolesnik, S. \& Pierson, R. N. (2000). Anthropometry in Body Composition An Overview. Ann N Y Acad Sci, 904, 317-326.

45. Wang, Z.M., Pierson, R. N. \& Heyms, S. B. (1992). The five-level model: a new approach to organizing bodycomposition research. The American Journal of Clinical Nutrition, 56(1), 19-28. https://academic.oup.com/ ajcn/article-abstract/56/1/19/4715618

46. Weber, D. R., Moore, R. H., Leonard, M. B. \& Zemel, B. S. (2013). Fat and lean BMI reference curves in children and adolescents and their utility in identifying excess adiposity compared with BMI and percentage body fat. American Journal of Clinical Nutrition, 98(1), 49-56. https://doi.org/10.3945/ajcn.112.053611

47. WHO. (n.d.). WHO $\mid$ BMI-for-age (5-19 years). Retrieved June 18, 2020, from https://www.who.int/growthref/ who2007_bmi_for_age/en/

48. WHO. (2016). Obesity and overweight Fact sheet No 311.

49. WHO Expert Committee. (1995). Physical Status: The Use and Interpretation of Anthropometry.

50. Yamaguchi, C. M., Faintuch, J., Silva, M. M., Modolin, M., Hayashi, S. Y. \& Cecconello, I. (2012). Interference of silicone breast implants on bioimpedance measurement of body fat. Clinical Nutrition, 31(4), 574-576. https://doi.org/10.1016/j.clnu.2012.01.009

51. Yu, O. K., Rhee, Y. K., Park, T. S. \& Cha, Y. S (2010). Comparisons of obesity assessments in over-weight elementary students using anthropometry, BIA, CT and DEXA. Nutrition Research and Practice, 4(2), 128. https://doi.org/10.4162/nrp.2010.4.2.128 